\title{
BETEKENIS EN FUNKSIE VAN 1 PETRUS 2:21B-25
}

\author{
J.H. Barkhuizen \\ (Universiteit van Pretoria)
}

\begin{abstract}
The meaning and function of 1 Peter 2:21b-25

First Peter addresses the Christians in the five Roman provinces in Asia Minor, and can in general terms be described as a letter of consolation and encouragement. Although they are suffering discrimination and injustice as a consequence of their faith in Christ, they should remember that they are in this world, but not from this world; that God has given them a new life through the resurrection of Christ; that they were born into a living hope of an inheritance that nothing can destroy or spoil. Within this broader picture of First Peter, the hymn in 2.21b-25 functions on two levels: firstly it exhorts the Christian house servants to obey their owners, although they are suffering without cause; as motivation the hymnal fragment deals with the suffering of Christ. He was without sin, yet He took their sins upon Him when He died at the cross, without retribution, thus leaving them an example to follow; secondly, it is pointed out that the author had with this hymn also the broader Christian community in mind (= servant paradigm), since they are all 'servants and slaves of God'. Apart from its function within First Peter as a whole, the paper also deals with the possible origin, demarcation, strophic structure and contents of the hymn.
\end{abstract}

\section{Doelstelling}

Naas die eulogie in 1 Petrus 1:3-12 ${ }^{1}$, bevat hierdie brief nog twee 'moontlike' liedfragmente wat handel oor die lyding van Christus ter wille van sondaars, in hierdie geval met spesifieke verwysing na die ontvangers van die brief. Hulle word aangespreek as gelowiges in die vyf Romeinse provinsies, wat oor die grootste gedeelte van Klein-Asië gestrek het. In besonder het hulle hulle bevind te midde van verontregtinge en diskriminasie van die kant van die Romeinse owerhede, Jode en onbekeerde huisgenote. Die brief is dan veral daarop gerig om hulle in hierdie benarde omstandighede te troos: hulle is God se nuwe mense, wat, omdat hulle in Hom glo en Hom liefhet, deur God se mag bewaar word tydens hulle verblyf as vreemdelinge.

Die doel van hierdie artikel is om veral die betekenis en funksie van 1 Petrus 2:21b-25 binne die breëre trooskarakter van die brief te omskrywe. Die funksie sal bekyk word vanuit twee perspektiewe: (i) die onmiddellike omgewing waarin dit geplaas is, en (ii) die breëre konteks van die brief. Met die oog op die vasstelling van die betekenis daarvan, verdien die vol- 
gende aspekte vooraf die aandag:

- die oorsprong/aard van die liedfragment in 1 Petrus 2:21b-25,

- die presiese afbakening daarvan,

- die vasstelling van die (strofiese) struktuur,

- $\quad$ vasstelling van die basiese temas

\section{Teks: oorsprong, afbakening, struktuur en temas}

\subsection{Teks: 1 Petrus 2:21b-25}

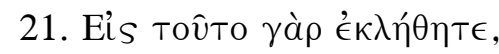

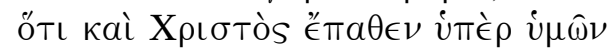

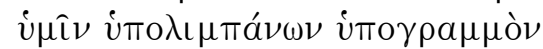

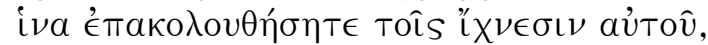

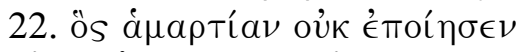

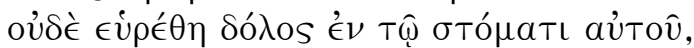

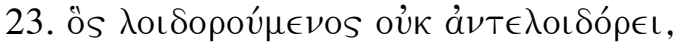

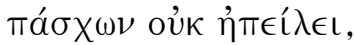

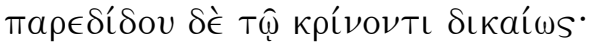

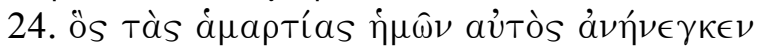

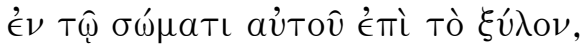

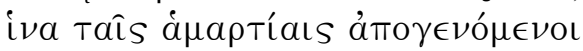

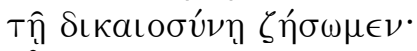

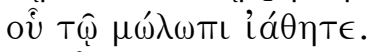

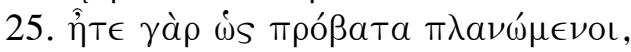

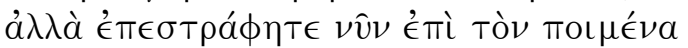

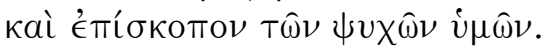

(21) Hiertoe is julle geroep, ${ }^{3}$ omdat ook Christus vir julle gely het, en so vir julle ' $n$ voorbeeld nagelaat het sodat julle in sy voetspore kan volg. (22) Hy het (geen) sonde gedoen nie, en bedrog is nie in sy mond gevind nie (23) Toe Hy beledig is, het Hy nie terug beledig nie, toe Hy gely het, het Hy nie gedreig nie, maar dit oorgegee aan Hom wat regverdig oordeel. (24) Hy het self ons sondes gedra in sy liggaam aan die kruis, sodat ons, nadat ons die sonde afgesterf het, vir die geregtigheid kan lewe; omdat Hy gewond is, ${ }^{4}$ is julle genees. (25) Want julle was soos dwalende skape, maar nou het julle teruggekeer na die Herder en Opsigter van julle lewe.

\subsection{Oorsprong/Aard}

Die gedeelte (2:21b-25) vertoon onmiskenbaar himniese trekke, wat verskeie geleerdes tot die aanname gebring het dat dit oorspronklik 'n himne was. ${ }^{5}$ Hierdie himniese trekke sluit onder andere die volgende in: ${ }^{6}$

- Die gebruik van die relatiewe voornaamwoord ös in verse 22,23 , en 24.

- Die opsomming van 'n aantal karakteristieke deugde van 'n persoon (verse 22 en 23).

- Voorbeeldige karakter van die persoon (verse 21 en 25).

- Kompendium-karakter: essensiële elemente gekonsentreerd op die persoon - heldedade in belang van mense (verse 21 en 24).

- Die verskuiwing van persoonlike voornaamwoorde van tweede na eerste, en weer na tweede persoon. 
- Die feit dat dit gerig is tot 'n wyer gehoor as die huisbediendes, en dus buite die huiskneg-konteks ewe goed kan figureer. ${ }^{7}$

Alhoewel Achtemeier ${ }^{8}$ argumenteer dat bogenoemde kenmerke nie noodwendig bewys dat dit oorspronklik 'n himne was nie, kan die poëtiese aard daarvan nie ontken word nie. Die outeur se besondere gebruikmaking van Jesaja 53, wat daarin bestaan dat hy Jesaja 53:4-7, 9 en 11-12 aanwend sodat dit 'ritmies' inpas binne die beskrywing van Christus se lyding, dien verder om die poëtiese aard van hierdie verse te onderstreep. Só kan die gedeelte gelees word as 'n himniese toepassing van die profete-teks (Jes. 53) op die persoon van Christus. Hierby dien ook gewys te word op die vae gebruik van Jesaja 53 in Markus 10:45 en Hebreërs 9:28, die fragmentariese verwysing daarna in Romeine 4:25a, en die feit dat in Mathheus 8:17, Lukas 22:37 en Handelinge 8:32-33 dit nie uitgewerk word ten opsigte van Jesus se lyding nie. Hierdie uitgebreide verwerking of gebruik van Jesaja 53 dui inderdaad dan ook op 1 Petrus as 'n belangrike bron oor die vroegste Christelike interpretasie van Jesaja 53. Die feit dat hierdie 'lied' uit en uit net van Christus se lyding melding maak, ${ }^{9}$ het Deichgräber ${ }^{10}$ daarna laat verwys as die eerste oorgelewerde lydingslied van die Kerk.

Die volgende parallelle toon aan in watter mate die skrywer van Jesaja 53 gebruik gemaak het:

1 Petrus 2

(21) Christus het vir julle gely

(22) geen sonde of leuens uit sy mond

(23) geen vergelding

(24) Hy het ons sondes gedra

(24b) genesing deur sy wonde

(25) julle het soos skape rondgedwaal

\section{Jesaja 53}

(4) Hy het ons lyding op Hom geneem

(9) geen sonde of leuens uit sy mond

(7) Hy het geduldig gebly ... nie gekla

(11/12) hy sal die straf vir hulle sonde dra... Hy het sondes van baie op Hom geneem

(5) genesing deur sy wonde

(6) ons het almal soos skape gedwaal

\subsection{Afbakening}

Die 'lied' in 1 Petrus 2:21-25 word ingelei deur die frase 'Want hiertoe is julle geroep' (vers 21a), en van hieruit begin die verwysing na Christus se lyding, ingelei deur die frase 'omdat ook Christus gely het...' Die woorde 'Hiertoe is julle geroep' verwys na die konteks van 2:18-20, waarin die huisbediendes aangespreek word en opgeroep word om hulle aan hulle eienaars of huisbase te onderwerp. ${ }^{11}$ Die gedagte van 'om lyding te verdra 
wanneer die goeie gedoen word' (vers 20) staan op die voorgrond. Dan volg vers 21a ('Want hiertoe is julle geroep'), wat in $21 \mathrm{~b}$ dan, soos hierbo aangedui, gevolg word deur die verwysing na Christus se lyding.

As daar nou na hoofstuk 3:18 gekyk word, merk ons dat dit ingelei word deur die frase 'want ook Christus het eenmaal gely...' In die Grieks is dit

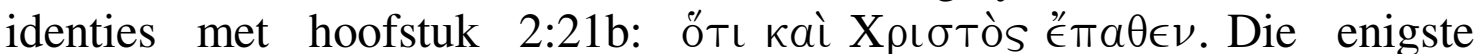

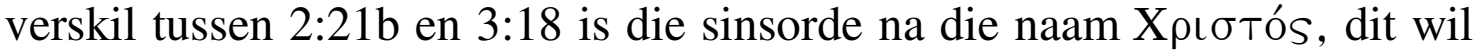
sê die terme wat verwys na sy lyding en vir wie of wat Hy gely het. Maar ook die onmiddellike konteks bevat dieselfde gedagte: dit is beter om te ly deur reg te doen as deur verkeerd te doen: $3: 17=2: 18-20$.

Ter vergelyking word 1 Petrus 3:18 aangehaal:

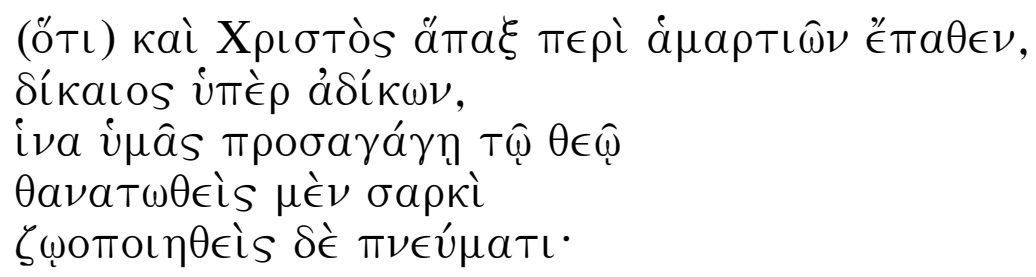

Dit lyk dus logies om, wat die afbakening betref in die geval van 2:21-25, die lied te laat begin met vers $21 \mathrm{~b}$, soos bevestig deur 3:18.

\subsection{Struktuur: strofes}

Wat die gedeelte 2:21b-25 betref, kan die afsonderlike verse as strofes gesien word, 'n indeling wat gesteun word deur (i) formele en (ii) inhoudelike elemente.

Formeel (vir die inhoudelike, kyk onder 2.5) word verse 22-24 elk ingelei deur die relatiewe voornaamwoord ôs, en die relatiewe voornaamwoord dien juis dikwels in Nuwe Testamentiese en post-Bybelse liedere as afbakeningsbeginsel. ${ }^{12}$ Die eulogie in 1 Petrus 1.3-12 maak tewens ook van hierdie beginsel gebruik. ${ }^{13}$ Hiervolgens kan die volgende strofes aangemerk word:

strofe $1=$ vers $21 \mathrm{~b}$ (met weglating van die begin-ö $\tau$ )

strofe $2=$ vers 22

strofe $3=$ vers 23

strofe $4=$ vers 24

strofe $5=$ vers 25 


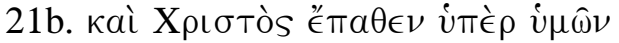

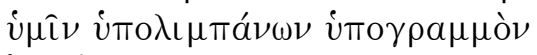

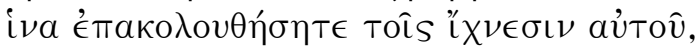

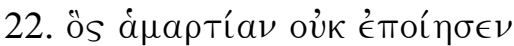

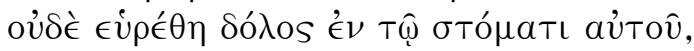

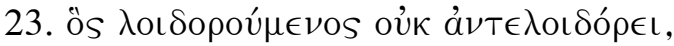

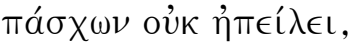

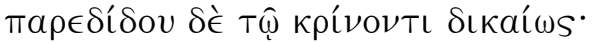

21b. Want ook Christus het vir julle gely, en so vir julle 'n voorbeeld nagelaat het sodat julle in sy voetspore kan volg.

(22) Hy het (geen) sonde gedoen nie, en bedrog is nie in sy mond gevind nie

(23) Toe Hy beledig is, het Hy nie terug beledig nie, toe Hy gely het, het Hy nie gedreig nie, maar dit oorgegee aan Hom wat regverdig oordeel.

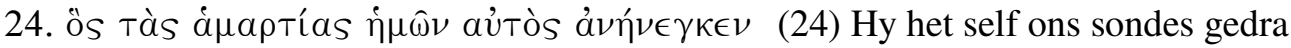

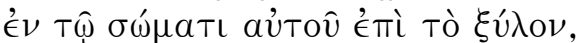

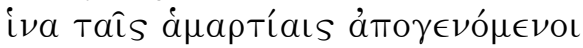

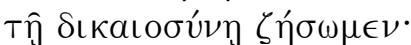

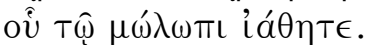

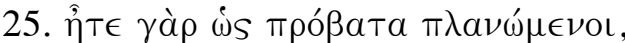

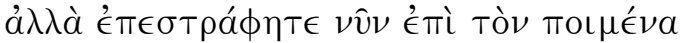

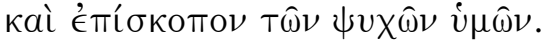

in sy liggaam aan die kruis,

sodat ons, nadat ons die sonde afgesterf het, vir die geregtigheid kan lewe; deur sy wonde is julle genees.

(25) Want julle was soos dwalende skape, maar het nou teruggkeer na die Herder en Opsigter van julle lewe.

Ter wille van volledigheid, volg hieronder die rekonstruksie van Deichgräber, ${ }^{14}$ wat tel onder dié wat 'n oorspronklike lied aanneem:

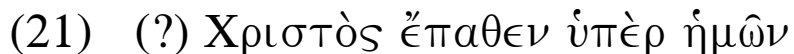

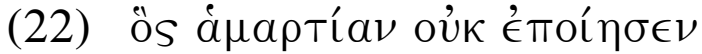

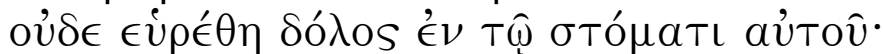

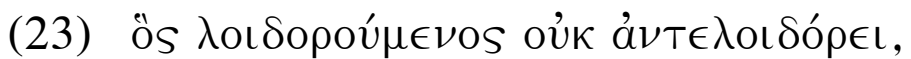

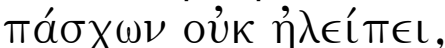

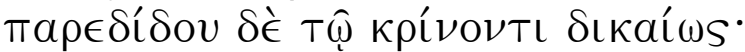

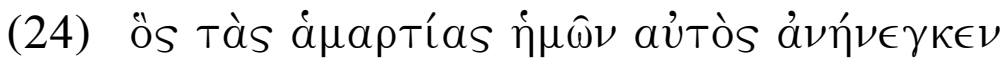

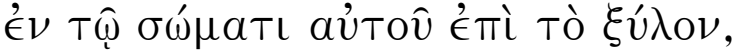

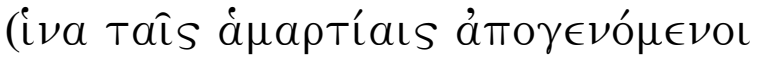

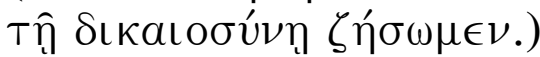

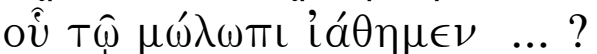

\subsection{Temas}

By die vasstelling van die tema(s) van 1 Petrus 2:21-25 kan dit voordelig vergelyk word met 3:18: nie net kontekstueel nie (die gedagte van onverdiende lyding), maar ook inhoudelik is daar 'n duidelike ooreenkoms tussen dié twee gedeeltes. 


\section{Petrus 2:21b-25}

- Vers 21b: Christus het (vir julle) gely = A.1

- Vers 21c-d: Die effek van sy lyding: Sy voorbeeld moet nagevolg word $=\mathbf{B}$

- Verse 22-23: Die karakter van Christus se lyding = A.2

- Vers 24a-b: Christus het vir ons sondes gely = A.1

- Verse 24c-25: Die doel en resultaat van sy lyding en sterwe (onder andere verbeeld deur ' $n$ mediese en herdersbeeld $=\mathbf{C . 1}$

\section{Petrus 3:18}

- Vers 18a: Christus het vir die sondes gely = A.1

- $\quad$ Vers 18b: Die karakter van Christus se lyding = A.2

- Vers 18c: Die doel en resultaat $=\mathbf{C . 1}$

- Vers 18d-e: Die karakter van sy lyding = A.2

Vier temas of motiewe kan derhalwe identifiseer word:

1. Die feit van Christus se lyding (A.1)

2. Die karakter van sy lyding (A.2)

3. Die doel en resultaat van sy lyding (C.1)

4. Die effek van sy lyding (B)

\section{Betekenis en Funksie van 1 Petrus 2:21b-25}

\subsection{Betekenis: inhoud van $2.21 \mathrm{~b}-25$}

Die ǑTl-sin, waarmee die gedeelte begin, dui die rede aan waarom die Christen-huisknegte opgeroep word om aan hulle werkgewers onderdanig te wees, al moet hulle onverdiende lyding verduur: naamlik omdat Christus dieselfde 'roeping' vervul het in sy lyding. Dit is hierdie lyding van Christus wat dan die hooftema van die 'lied' is. Vervolgens word dan gelet op die vier aspekte van Christus se lyding, soos hierbo geïdentifiseer is.

- Die eerste aspek raak die grondgedagte van Christus se lyding (verse $21 b, 24 a-b)$. Terwyl die uitdrukking in $21 b$ "̈ $\pi a \theta \in \nu$ (=3.18) sowel op sy lyding as sy dood kan dui, word sy lyding eksplisiet in 24b aan sy dood gekoppel: naamlik dat hy die sondes in sy liggaam aan die kruis gedra het (kyk Jes.53:4,12). Die kruis word hier omskrywe as

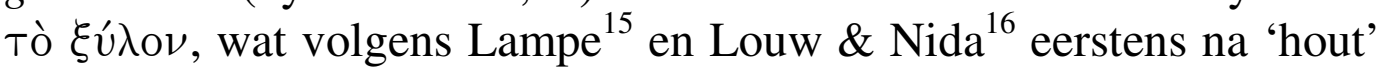


verwys, en dan na bepaalde voorwerpe wat van hout gemaak is. In dié sin roep dit Deut. 21:22-23 na vore, en word dit deur Paulus in Gal.3:13 aangehaal (kyk ook Hand.5:30 en 10:39). Maar die gebruik van die woord tò $\xi$ v́lov word hier verder bepaal deur die gebruik om die doodstraf van slawe in die Antieke juis deur kruisiging aan 'n houtpaal te voltrek. So word daar 'n noue band gelê tussen die lyding van die Christen-huiskneg en Christus se lyding, iets wat hieronder weer ter sprake sal kom. Die persone vir wie Christus gely het, word aangedui as 'julle', 'ons' = 'die siekes', 'die verdwaalde skape' - en die saak waarvoor Hy gely het, is 'die sondes'. Die feit dat die outeur

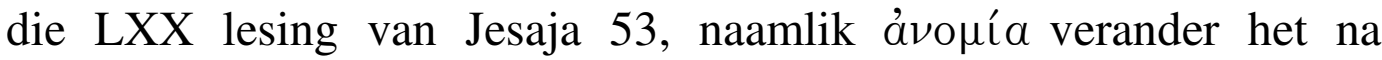
apaptíav, is waarskynlik onder invloed van vers 24 (Tàs

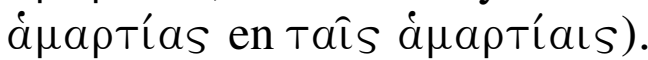

- Die karakter van Christus se lyding word in 22-23 uitgespel, naamlik dat Hy onskuldig was. Die verse kom presies ooreen met die LXX van Jesaja 53:9b, behalwe dat ons hier 'sonde' het in die plek van 'wetteloosheid' (ávopíav) van die Jesaja-teks, wat te begrype is binne die konteks van Christus se lyding as 'n lyding vir die sondes (vers $24 c)$. In vers $23 a-b$ word die karakter van sy lyding verder omskrywe as sy nalaat van enige vorm van vergelding vir die vernedering met sy verhoor, ${ }^{17}$ maar wat ook teken was van sy hele lewe op aarde, soos die gebruik van die imperfektum hier wil benadruk. ${ }^{18}$ Hierdie nalaat van enige vergelding van sy kant af word bevestig deur 23c: Hy het dit aan God oorgelaat. Presies wat Christus aan God oorgelaat het, word nie aangedui nie: dit kan of na Homself verwys, sy saak, of dat sy vyande gestraf sal word, alhoewel laasgenoemde nie sou strook met Lukas 23:34 nie (Jesus se gebed vir sy vyande), en derhalwe afgewys moet word.

- $\quad$ 'n Derde aspek het te doen met die doel en resultaat van sy lyding. Vers $24 \mathrm{c}-\mathrm{d}$ dui die doel aan: sodat ons geen deel aan sondes sal hê nie, maar in geregtigheid sal lewe. In die eerste geval (24c) dui die

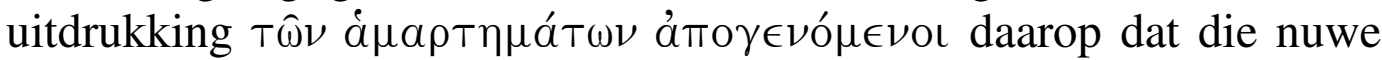
lewe in Christus voorafgegaan word deur 'n sterwensproses van die ou mens met sy sondige lewe. In die tweede geval (24d) dui die

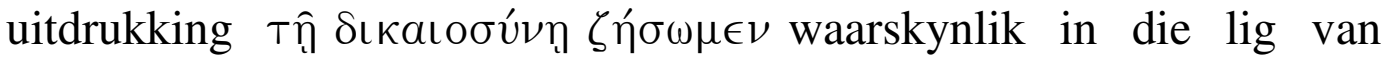
3:14, op die feit dat ons 'n lewe sal voer in ooreenstemming met God se wil. ${ }^{19}$ Die resultaat van Christus se lyding word deur 'n Jesaja-teks uitgelig, naamlik die mediese beeld van Jesaja 53:5 (die siekes is genees omdat Hy verwond is), met twee veranderings: oî vervang Jesaja se aủtôै, en die eerste persoon van Jesaja word vervang met die tweede persoon: $i a ́ \theta \eta \mu \epsilon \nu$ - $i a ́ \theta \eta \tau \epsilon$, laasgenoemde verandering is 
homileties van aard. Die mediese beeld van Jesaja vind natuurlik goeie aanklank in die Nuwe Testamentiese beeld van Jesus as die Geneesheer. Vers 25 omskrywe die resultaat met die skape-beeld (die verdwaalde skape het teruggekeer) uit Jesaja 53:6 (kyk ook Eseg. 34:5-6) en die Ou Testamentiese beeld van God as Herder, welke funksie in die Nuwe Testament deur Christus opgeneem is (Mat. 9:36; Joh.10:11-13;21:15-17; Openb. 717 en Heb.13.20), en in 1 Petrus self

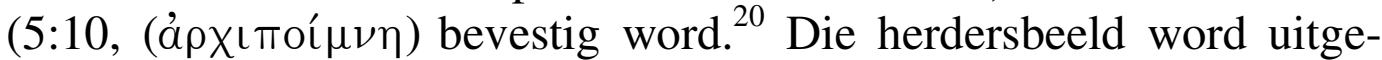
brei deur die woord 'Opsigter' of 'Bewaker' ('€тíбкотоS), 'n konsep waarmee God in die Ou Testament getipeer word (Job 20:29), maar hier weer eens met Christus verbind word. Dit is moontlik om dit as hendiadys te lees: die Herder wat oor ons hele persoon/lewe ${ }^{21}$ toesig

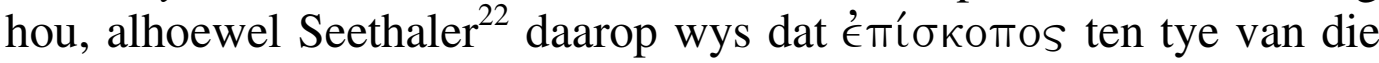
ontstaan van die Petrusbrief reeds as ampstitel in die kerk gegeld het, en daarop dui dat 'Christus im kirchlichen Amt wirkt und sich mit dem Amtsträger gleichsam identifiziert'.

- Die laaste aspek het te doen met die effek van Christus se lyding, wat in vers $21 \mathrm{c}$-d omskrywe word. Die effek van Christus se lyding was om vir Christene ' $n$ voorbeeld na te laat om na te volg. Aangesien die lyding van Christus vir die sondes van die mens 'n unieke heilsdaad was, en in of deur niemand anders herhaal kan word nie, is die 'voorbeeld van Christus' waarna hier verwys word, nie 'n identiese imitatio Christi nie, maar ' $\mathrm{n}$ bepaalde lewenspatroon wat deur Christene, as deel van hulle nuwe lewensruimte in Christus, binne die werklikheid van hierdie wêreld navolg moet word. Buitendien gaan dit in 2:22-23 nie oor sy plaasvervangende lyding nie, maar van sy verdraagsame lyding, dws die wyse waarop Jesus met geduld en sonder enige dreigement van sy kant af gereageer het op gesagsdraers se verontregtende optrede en gedrag. In hierdie opsig word Jesus se optrede wel 'n voorbeeld vir gelowige huisknegte om na te boots.

\subsection{Funksie: die huiskneg-paradigma}

3.2.1 1 Petrus 2:11-3:12 omvat een van die hoofdele van die brief, met as tema: Die Christen in die wêreld. Hierdie tema word op vyf vlakke uitgewerk:

- Die Christen se getuienis onder die heidene (2:11-12)

- Die Christen as burger (2:13-17)

- Die posisie van die Christen-huiskneg (2:18-25)

- Die Christelike huwelik (3:1-7)

- $\quad$ Die Christelike gemeenskap (3:8-12) 
Hoofstuk 2:18-25 gaan dus oor die posisie van die Christen-huisknegte. Saam met tekste soos Kol.3:18-4:1, Ef.5:22-6:9, 1 Tim.2:8-15; 5:3-8, Tit.2:2-10 en Didache 4.11, vorm 1 Petrus 2.18 e.v. deel van die sogenaamde Haustafeln ${ }^{23}$, 1985:35-36), wat afwyk van pre-Christelike huis-kodes deurdat slawe nooit daarin vermeld word nie. Uit die feit dat hier geen advies tot huisbase gerig is nie, maar net tot huisknegte, is die ongegronde afleiding gemaak dat daar geen of weinig sodanige persone hulle onder die geadresseerders bevind het, of dat die geadresseerders merendeel slawe of huisknegte was. ${ }^{24}$ Die aanname van 'n huisknegparadigma het ten doel om 'n ander rede te soek vir die feit dat die outeur soveel aandag hier aan die Christen-huisknegte bestee (kyk onder 3.2.2).

In die algemeen was die regsposisie van slawe in die Romeinse Ryk uiters haglik. ${ }^{25}$ Volgens die Romeinse reg was die slaaf die besitting van sy eienaar, in so 'n mate dat selfs huwelike onder slawe geen wettige erkenning geniet het nie, en die kinders gebore uit só 'n huwelik tot die huisbaas behoort het. In lyn met hierdie regsposisie is slawe dikwels onmenslik behandel, en is dislojaliteit in watter vorm ookal, swaar gestraf. Die doodstraf het gewoonlik in die vorm van kruisiging bestaan. Die feit dat slawe soms geweldadig op hierdie situasie van hulle gereageer het, is te begrype. $^{26}$

Die posisie van Christen-slawe is, soos wat dit deur Paulus verwoord is, in 'n nuwe tradisie geplaas: in Christus word alle onderskeidinge in ras, geslag en sosiale status opgehef (Gal.3:28; 1 Kor.12:13). Deur hulle gemeenskap met Christus het die vroeë Christelike gemeenskap 'n nuwe lewensruimte betree, waarin gewone sosiale onderskeidings, wat nog harde werklikheid in die wêreld om hulle was, opgehou het om te bestaan - of voorgehou word as die beginsel waarvolgens gelowiges hulle lewensomgang en -verhoudings moet inrig. ${ }^{27}$ Daarom, al word die Christenslaaf in 1 Kor.7:21 aangemoedig om sy vryheid te bekom as die geleentheid daartoe sou opduik, wys dieselfde teksvers ook daarop dat slaafskap nie as kwelling ervaar moet word nie. 1 Petrus 2.18 e.v. sluit hierby aan deur Christen-huisknegte aan te moedig tot die ware Christen-gedrag in die aangesig van lyding en hulle algemene ongunstige sosiale posisie. Want die gevaar sou kon bestaan dat Christen-huisknegte as gevolg van hulle gelykheid in Christus met ander gelowiges, hulle vryheid, wat hulle in Christus gevind het, verkeerd sou kon verstaan. Maar juridies was hulle nog huisknegte (of slawe) en onvry, en daarom die vermaning of oproep dat hulle gehoorsaam moet wees aan hulle huisbase, en dan nie net aan dié wat hulle goedgesind is nie, maar ook en juis aan dié wat hulle onregverdig 
behandel.

Die skrywer van 1 Petrus roep die Christen-huisknegte om hulle te ondewerp aan hulle huisbase omdat hulle dit aan God verskuldig is (verse 18-20). Dit is immers die implikasie van die woorde 'met alle vrees' in vers 18 , wat verwys na 'vrees vir die Here', en nie 'vir hulle eienaars nie'. Onverdiende lyding is geen ligte aangeleentheid nie, en dit is alleen genade as hulle dié lyding verduur op grond van 'n gewete wat geheel en al op God gerig is. In die uitdrukking $\delta \iota \grave{a} \sigma v \nu \in \hat{l} \delta \eta \sigma \iota \nu \theta \in o \hat{v}$ moet die genitief $\theta \epsilon o \hat{v}$ as objeksgenitief verklaar word, terwyl $\sigma v \nu \epsilon i \delta \eta \sigma ı s$ heenwys na die mede-wete wat die persoon deel met die ander gelowiges as volk van God, dus: 'n kennis van wat God se wil is. In dié lyn omskrywe Louw \& Nida ${ }^{28}$ dit ook: 'if you endure the pain of undeserved suffering because you are conscious of God's will', terwyl Windisch ${ }^{29}$ dit treffend omskrywe as 'die innere Gebundenheit an Gott, die Gehorsam zu Bösem zu weigern, aber Unrecht zu dulden...'

As motivering ${ }^{30}$ hiervoor geld die voorbeeld van die lyding van Christus. Ook Christus het onreg gely maar dit met groot geduld verdra. ${ }^{31}$ Alhoewel Hy onskuldig was, het Hy gely, en so moet die Christen-huisknegte ook optree wanneer hulle goed doen en nogtans lyding verduur. Aangesien die verlossingsdaad van Christus hulle lewensstatus van negatief (sondaars) tot positief (verlostes) verander het, 'n verandering wat in terme van 'n nuwe geboorte, wat tot 'n nuwe lewe lei, omskrywe word (1 Petrus 1:3;23), moet ook hulle nou uit dankbaarheid gereed wees om sy voorbeeld (in sy voetspore) te volg, wat niks anders is nie as 'n roeping tot dissipelskap.

3.2.2 Hierdie oproep tot Christen-huisknegte het egter ook 'n universele karakter. Verskeie geleerdes ${ }^{32}$ meen dat die skrywer die Christenhuisknegte aanspreek omdat hulle tipies is van die weerlose kwesbaarheid

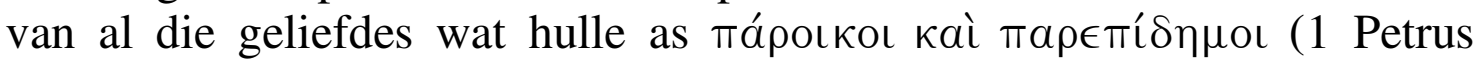
2:11) binne die Romeinse Ryk bevind. Hulle is almal immers diensknegte

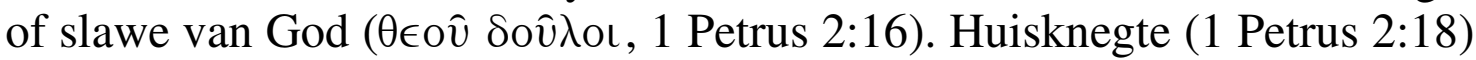
of slawe (1 Petrus 2:16) in hierdie konteks het daarom 'n 'paradigmatiese betekenis: hulle verteenwoordig die gelowiges se algemene posisie binne die Romeinse Ryk. Die uitdrukking 'vir ons sondes' neem duidelik die saak verder as bloot 'oortredings' van huisknegte of slawe, terwyl die eis van gehoorsaamheid aan werkgewers, wat tot die Christen-huisknegte/slawe gerig is, weerklank vind in die eis van gehoorsaamheid aan die staat wat tot al die geadresseerdes in die algemeen gerig is (2:13-17). Verder is dit belangrik, wat hierdie paradigmatiese funksie van die slawe-kode 
betref, om daarop te let dat die motief van die Christen se lyding in hierdie wêreld, wat ipso facto ook vir die Christen-huisknegte geld, soos 'n goue draad deur die brief loop, en dat dit juis gedra word deur die grondmotief van Christus se lyding as exemplum - maar dan lyding in die sin soos reeds hierbo omskrywe is, naamlik die wyse waarop Hy verontregting wat Hom aangedoen is deur gesagsdraers verduur het. Dit geld dus as parallelle motiveringslyn vir die lydingslyn van die uitverkorenes, soos blyk uit die onderstaande samevatting, wat drie duidelike sodanige parallelle aandui:

Eerste parallel:

- Die uitverkorenes is vreemdelinge en bywoners, maar omdat hulle in Christus nuutgebore is, en hulle glo, en hulle Hom liefhet, al sien hulle Hom nie, bewaar God hulle erfenis en hulleself vir die saligheid wat aan die einde openbaar sal word $(1: 5 ; 17 ; 23 ; 2: 11)$. Hulle moet derhalwe vreugde betoon te midde van hulle lydinge, want lyding is daar om die egtheid van hulle geloof te toets met die oog op eer en heerlikheid op die dag van die Here (1:6-7; vgl.1.9).

- Die Gees van Christus het deur die profete vooraf die lyding (en verheerliking) van Christus verkondig (1:11). Christus is die Lam van God (lydingsbeeld) wat vlekkeloos en sonder liggaamsgebrek is. Deur sy bloed (sterwe) is die gelowiges losgekoop (1:19). God het Hom uit die dood (lydingsbeeld) opgewek (1.20).

Tweede parallel:

- Oproep tot Christen-huisknegte om hulle aan hulle huisbase te onderwerp ten spyte van onverdiende lyding. Dit is immers genade wanneer hulle onverdiend ly. Daartoe is hulle geroep (2:18-21a).

- Christus het immers ook vir hulle gely: Hy het sy lyding met geduld verdra (2:21b-24). Hy het hulle sondes in sy liggaam aan die kruis gedra. Deur sy verwonding aan die kruis is hulle genees (2:24).

Derde parallel:

- Dit is 'n voorreg om te ly vir wat goed is (3:13-14). As dit die wil van God is dat hulle moet ly wanneer hulle goed doen, is dit goed (2:17). Wie gely het, het met die sonde afgereken (4:1-2). Vreugde as die gelowiges in Christus se lyding deel. As iemand ly omdat hy 'n Christen is, moet hy hom nie daaroor skaam nie. Hulle lyding is God se wil, en daarom moet hulle hul lewe aan Hom toevertrou (4:12-19). 
- Christus het as die onskuldige gely vir die skuldiges. Hy was as mens doodgemaak (3:18), en het liggaamlik gely $(4: 1,13)$.

Hoe seer die gelowiges as gemeente van God deel het aan Christus se lyding en aan mekaar, blyk uit die slot van die brief. In 5:9-10 kom die skrywer weer terug na die lyding van die gelowiges: hy wys weer daarop dat hulle lyding slegs van korte duur sal wees, maar sodat hulle standvastig kan bly, hou hy twee motiveringe aan hulle voor: (i) dat hulle moet onthou dat Christus hulle geroep het (nie net tot lyding vir sy Naam nie, maar ook) om deel te hê aan sy heerlikheid; en (ii) dat hulle moet weet dat dwarsdeur die wêreld hulle medegelowiges dieselfde soort lyding moet verduur!

\subsection{Slot: die eskatologiese gemeente en lydingsteologie van 1 Petrus}

Deur 'n nuwe skepping van die kant van God, wat deur die opstanding van Jesus Christus teweeggebring is, het die gelowiges, die gedooptes, 'n stuk vreemde korpus in hulle wêreld geword, waarvan die Joodse gemeente in Qumran as model gesien kan word. Hulle word derhalwe in 1 Petrus 1:13 opgeroep om die 'lendene van hulle verstand te omgord', en met 'n nugtere lewensstyl hulle hoop te vestig op die genade wat tot hulle sal kom op die dag van Christus se openbaring. Laasgenoemde uitdrukking, naamlik

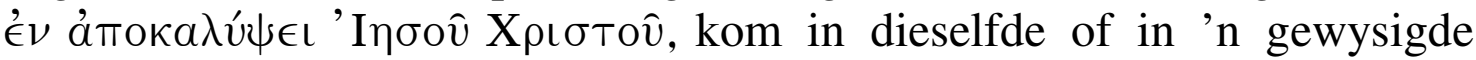
vorm, tweemaal voor in die direkte voorafgaande eulogie, maar ook later in die brief in $2: 12,4: 14,5: 2$ en 5:10, en dui op en beklemtoon die eindbestemming van die Christelike gemeente. Die gelowiges is voortaan vreemdelinge $(1: 1 / 17)$, en sal derhalwe tot op dié dag lydinge (of diskriminasie) ervaar (as vreemde korpus in die heidense wêreld) (1:6), want hulle is God se uitverkorenes (1:1), heiliges (1:16), en sy volk (2:9). Hulle is dus 'vreemde korpus'-gemeente deur die geloof, en nie deur onttrekking uit die wêreld, soos die Esseners dit opgeneem en beoefen het nie. Daarom die uitvoerige 'aanbevelinge' aan die Christengemeente ten opsigte van hulle posisie en verhoudinge binne die heidense wêreld. En binne hierdie konteks vorm 1 Petrus 2:21b-25 derhalwe saam met ander prominente gedeeltes in die brief, 'n kragtige motivering om die gelowiges in KleinAsië, en gelowiges van alle tye, aan te spoor en te vertroos wanneer hulle hier as God se "vreemdelinge" lydinge en beproewinge ervaar, nie as straf op die kwaad wat hulle gedoen het nie $(3: 17),{ }^{33}$ maar omdat hulle as eskatologiese gemeente nie aan hierdie wêreld gelykvormig kan wees nie, omdat hulle God se mense is wat wag op en lewe vir die dag van Jesus Christus se openbaring aan die einde van die tyd. 


\section{NOTAS}

1

J.H.Barkhuizen, 'Die eulogie in 1 Petrus 1:3-12', In die Skriflig 36 (1), 2002, 45-66.

Die teks word hier weergegee soos dit gedruk is in E.Nestle \& K.Aland, Greek-English New Testament, Stuttgart: Deutsche Bibelgesellschaft, 1981, 602-603.

Vir die weglating van $\gamma \grave{\alpha} \rho$ as merker van 'n nuwe sin, vergelyk J.P.Louw \& E.Nida, Greek-English Lexicon of the New Testament based on Semantic Domains, New York: United Bible Society, II, 811.

So Louw \& Nida, II,231.

Kyk hiervoor veral R.Bultmann, Bekenntnis- und Liedfragmente im ersten Petrusbrief, Conjectanea Neotestamentica 11 in Honorem Antonii Fridrichsen, Lund: G.W.K. Gleerup, 1947, 12; E.Lohse, 'Paränese und Kerygma im 1.Petrusbrief', Zeitschrift für Neutestamentliche Wissenschaft, 45 (1954) 58; R.P.Martin, 'The Composition of 1 Peter in Recent Study', Vox Evangelica, 1 (1962) 31; R.Deichgräber, Gotteshymnus und Christushymnus in der frühen Christenheit. Untersuchungen zu Form, Sprache und Stil der frühchristlichen Hymnen, Göttingen: Vandenhoeck \& Ruprecht, 1967, 140 en nota 5; H.Schlier, 'Eine Adhoratio aus Rom: Die Botschaft des Ersten Petrusbriefs, in: Schlier, H (red.) Strukturen Christlicher Existenz: Festgabe P.Friedrich Wulf, Würzburg: Echter, 1968, 60. Deichgräber (p.143) wys op 'n Hellenistiese, teenoor 'n Palestynse herkoms; en E.Krentz, 'Epideiktik and Hymnody: The New Testament and Its World', Biblical Research 40 (1995), 50-97.

Kyk in die algemeen E.Norden, Agnostos Theos. Untersuchungen zur Formgeschichte religiöser Rede, Darmstadt, 1956, 143-263, en veral Krentz (nota 5), wat die volgende algemene kenmerke van himnes/himniese passasies opnoem: (1) inleidende aanroep; (2) versoek tot hulp; (3) afsluitende bede; (4) verhewe aard van die onderwerp; (5) individuele kragte/deugde van die geprese persoon; (6) vroëre heldedade; (7) goddelike afkoms; (8) onsterflike natuur; (9) en openbaring voor mense.

Kyk O.Osborne, 'Guide Lines for Christian Suffering: A Source-Critical and Theological Study of 1 Peter 2,21-25, Bib., 1983, 381-387; en G.J.van Wyk \& F.J.van Rensburg, 'O'Kא́́taı (Huisbediendes) in die eerste-eeuse Grieks-Romeinse samelewing. 'n Sosio-historiese konstruksie vir die interpretasie van 1 Petrus 2:18, In die Skriflig 31(3) (1997), 229-249.

P.J.Achtemeier, A Commentary on First Peter, Minneapolis: Fortress, 1996, 192-193.

Indien aanvaar word dat ons hier wel met 'n oorspronklike lied te make het, ontstaan die vraag of die oorspronklike lied wel na Jesus se pre-eksistensie en verhoging verwys het (soos in die lied van Filippense 2:6-11), maar wat hier om kontekstuele redes (homileties) weggelaat is. 
Deichgräber, 142.

Kyk veral die artikel van van Wyk \& van Rensburg hierbo gesiteer.

Kyk Deichgräber, 142, en Krentz (nota 6).

Kyk Barkhuizen, 49.

Deichgräber, 142.

G.W.H.Lampe, A Patristic Greek Lexicon, Oxford: Clarendon Press, 1982, 933-934.

16 Louw \& Nida, II, 36.

Kyk Mk.14:61; 15:5; Mat.26:62-63; 27:12,14; Lk.23:9 en Joh.19:9.

Kyk Achtemeier, 200.

19 Die nuwe lewe $(1: 3)$ of nuwe geboorte $(1: 23)$ is een wat losgemaak is van die sonde en gerig is op die wil van God. Kyk ook Tit. 2:12 en 1 Joh.4:9. Kyk verder ook Hebr.13:20; Openbaring 7:17.

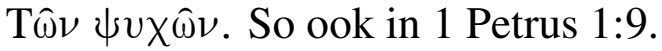

P-A. Seethaler, 1. und 2. Petrusbrief/Judasbrief, Stuttgarter Kleiner Kommentar. Neues Testament 16. Stuttgart: Verlag katholisches Bibelwerk $\mathrm{GmbH}, 1985,38$.

Kyk hiervoor D.H.Balch, 'Household Codes', in: D.E.Aune (red.), GrecoRoman Literature and the New Testament: Selected Forms and Genres, Atlanta: Scholars Press, 188, 46; en Seethaler, 35-36. Onder andere J.D.N. Kelly, The Epistles of Peter and Jude, London: Adam \& Charles Black, 1969, 114-115.

Kyk in die algemeen E.A.Judge, The Social Pattern of the Christian Groups in the First Century, London: Tyndale Press, 1960.

26 Ekonomies was die slawe/huisknegte egter baie beter daaraan toe. Kyk S.Dickey, 'Some Economic and Social Conditions of Asia Minor Affecting the Expansion of Christianity', in: S.J.Case (red.), Studies in Early Christianity, New York: Century, 1928, 402-403. Kyk Gal.3:28; 1 Kor.12:13; Kol.3:11, en Filemon 8-18.

Louw \& Nida, I, 28.4.

29 H.Windisch, Die Katholischen Briefe, Tübingen: Verlag JCB Mohr, 1930, 64.

30 Kyk L.Thurén, Argument and Theology in 1 Peter. The Origins of Christian Paraenesis, Sheffield: Sheffield Academic Press, 1995, veral hoofstuk 3: 'Identifying the Motivating Expressions'.

31 Kyk onder andere Mat.11:29, 1 Tes.1:6, II Tes.3:5, Fil.2:5, en Heb.12:2.

32 Kyk o.a. J.H.Elliott, A Home for the homeless: A Sociological Exegesis of 1 Peter, Its situation and strategy, Philadelphia: Fortress, 1981, 206-207, en Schlier, 78.

33 Vir die gedagte van onverdiende lyding teenoor lyding wat as straf ervaar word, vergelyk naas Mat.5:46 e.v. ook Plato, Gorgias 509c. 